\title{
Assessment of Heavy Metals Contamination and Enzymatic Activity in Pine Forest Soils under Different Levels of Anthropogenic Stress
}

\author{
Marta Kandziora-Ciupa*, Ryszard Ciepal, Aleksandra Nadgórska-Socha \\ University of Silesia, Department of Ecology, Bankowa 9, PL 40-007, Katowice, Poland
}

Received: 10 September 2015

Accepted: 16 February 2016

\begin{abstract}
The aim of this work was to assess heavy metal concentrations and the effects of these metals on soil enzymatic activity in polluted and potentially unpolluted forest areas. The study was performed in typical pine forests located in three heavily polluted (in the immediate vicinity of a zinc smelter, an iron smelter, and a power plant) and three relatively clean sites (a nature reserve, an ecological site, and an unprotected natural forest community) in southern Poland. The research concerned the activity of acid phosphatase, dehydrogenase, $\beta$-glucosidase, and urease. In the soils, taken from the top 0-10 cm layer, we also tested the concentrations of heavy metals $\left(\mathrm{Cd}, \mathrm{Fe}, \mathrm{Pb}\right.$, and $\mathrm{Zn}$ ) extracted with $10 \% \mathrm{HNO}_{3}$ and $0.01 \mathrm{M} \mathrm{CaCl}_{2}$, and their $\mathrm{pH}$ and organic matter contents. Single pollution index and Nemerow pollution index were also calculated.

Nemerow pollution index indicated serious pollution with heavy metals at two sites. The lowest activity of soil enzymes (acid phosphatase, and in particular $\beta$-glucosidase) was found in the site with the highest levels of heavy metals. In this study we found no effect of organic matter on the activity of the selected enzymes. There was a significant effect of $\mathrm{pH}$ on the activity of acid phosphatase and $\beta$-glucosidase.
\end{abstract}

Keywords: heavy metals, pollution index, soil enzymes

\section{Introduction}

Soil plays a vital role in life organisms, not only for anchorage and source of nutrients but also as a sink to many industrial wastes - most of which are hazardous [1, 2]. Changes in some soil properties may occur very slowly or may only occur when the soil undergoes drastic changes. Such properties are not suitable for estimating soil quality, and properties that respond rapidly to environmental stress must be used [3]. Evaluating the quality and the productivity of the soil is an important part in studying the natural environment [4]. Heavy metals are one of the most significant components of environmental pollution, exerting long-term risky effects on soil ecosystems and negatively influencing biological processes in the soil, hence the need for constant monitoring and regulation of their concentrations in soil [5]. Heavy metals generally affect the growth, morphology, and metabolism of microorganisms that lead to a decrease in the functional diversity of soil ecosystems [6]. Heavy metals can inhibit enzyme activities by interacting with the enzyme substrate complexes, denaturing the enzyme protein and interacting with their active sites [7]. Enzymatic activities are frequently used for determining the influence of various pollutants - including heavy metals - on soil microbiological quality $[8,9]$.

*e-mail: marta.kandziora-ciupa@us.edu.pl 
The activity of soil enzymes is considered a good bioindicator that reflects the natural and anthropogenic disturbance of the soil and shows a quick response to changes induced in the soil ecosystem. Enzymes are secreted into the soil environment mainly by soil microorganisms, catalyzing biochemical processes crucial for forest soil fertility and productivity in forest ecosystems $[4,10-12]$. The evaluation of soil enzyme activity is one of the cheapest and easiest techniques that can be used to evaluate soil pollution $[5,13,14]$, being more sensitive to soil contamination and with reactions that are faster in comparison to the monitoring of the chemical and physical properties of the soil. In addition, changes in soil enzyme activity reflect the real impact of stress conditions from contamination on the growth and activity of soil microflora [15]. The aim of this work was to assess the heavy metal concentrations and study the effect of these metals on soil enzymatic activity in polluted and potentially unpolluted forest areas.

\section{Material and Methods}

The study was performed in coniferous forest ecosystems located in three heavily polluted sites in the immediate vicinity of the Miasteczko Ślaskie zinc smelter (M1), the ArcelorMittal Poland S.A. iron smelter in Dąbrowa Górnicza-Łosień (L2), and the Jaworzno III power plant in Jaworzno (J3), plus three potentially clean sites: Pazurek Nature Reserve in Jaroszowiec Olkuski (P4), the Płone Bagno ecological site in Katowice (PB5), and the unprotected natural forest community in Kobiór (K6). All of the sites were situated in southern Poland in Śląskie or Małopolskie provinces.

Soil samples were collected in May, July, and September 2009 to capture the dynamic variabilities during the 2009 growing season from depths of $0-10 \mathrm{~cm}$. Samples were collected at each site from five random sites within an area of $50 \mathrm{~m}^{2}$, and soil sub-samples were combined into a composite sample. Soil samples were kept at $4^{\circ} \mathrm{C}$ during transport to the laboratory. Soil enzyme activity was determined at field moisture levels in the soil samples, which were sieved through a $2 \mathrm{~mm}$ sieve and stored at $4{ }^{\circ} \mathrm{C}$ prior to microbial analysis. The activity of acid phosphatase, dehydrogenase, and urease were carried out in accordance with the methodology proposed by Schinner et al. [16].

The activity of acid phosphatase was tested by colorimetric method. The $p$-nitrophenol released by phosphomonoesterase activity was extracted and colored with sodium hydroxide and determined photometrically at $\lambda=400 \mathrm{~nm}$. The acid phosphatase activity was expressed in $\mu \mathrm{g}$ of $p$-nitrophenol ( $p$-Nf) $\mathrm{g}^{-1}$ d.m. $\mathrm{h}^{-1}$ (d.m. - dry matter). Triphenyltetrazolium chloride was the substrate used for the dehydrogenase activity determination. Triphenyl formazan (TPF) was extracted with acetone and measured photometrically at $\lambda=546 \mathrm{~nm}$. The dehydrogenase activity was expressed in $\mu \mathrm{g}$ TPF $\mathrm{g}^{-1}$ d.m. $16 \mathrm{~h}^{-1}$. The urease activity estimation was based on colorimetric determination of ammonium formation after enzymatic urea hydrolysis. Urease activity was expressed as $\mu \mathrm{gN}$ $\mathrm{g}^{-1}$ d.m. Saligenin released from salicin ( $\beta$-glucosidosaligenin) was determined colorimetrically after coloring with 2,6-dibromochinon-4-chlorimide, at $\lambda=546 \mathrm{~nm}$ for $\beta$-glucosidase activity estimation. $\beta$-glucosidase activity was expressed as $\mu$ g saligenin $\mathrm{g}^{-1}$ d.m. $3 \mathrm{~h}^{-1}[17,18]$.

The metal content in the soil was estimated according to the methods of Bouwmann et al. [19] and Ostrowska et al. [20], in air-dried soil samples that had been sieved through a $1 \mathrm{~mm}$ sieve. Metals were extracted from the soil with $0.01 \mathrm{M} \mathrm{CaCl}_{2}$ (potentially bioavailable elements) or with $2 \mathrm{M} \mathrm{HNO}_{3}$ (acid extracted elements). For the $\mathrm{CaCl}_{2}$ extraction, $5 \mathrm{~g}$ of soil with $50 \mathrm{ml}$ of $0.01 \mathrm{M} \mathrm{CaCl}_{2}$ solution was agitated for $5 \mathrm{~h}$. The $\mathrm{HNO}_{3}$-extractable fraction was obtained by agitating $10 \mathrm{~g}$ of soil sample with $100 \mathrm{ml}$ of $2 \mathrm{M} \mathrm{HNO}_{3}$ for $1 \mathrm{~h}$. The content of metals in the filtered extracts was measured by inductively coupled plasma-atomic emission spectroscopy (Spectro Analytical Instruments).

The single pollution index and Nemerow pollution index were calculated for acid-extracted elements. The pollution level by a given heavy metal (i) was evaluated with the single pollution index $(\mathrm{Pi})$ calculated as the ratio between the metal concentration $(\mathrm{Ci})$ in a soil sample and permitted standard of the same metal $(\mathrm{Si})$ :

$$
\mathrm{Pi}=\frac{\mathrm{Ci}}{\mathrm{Si}}
$$

Permitted standard for this study was recommended by the regulation of the minister of the environment about the standards of soil and ground quality $\left(300 \mathrm{mg} \mathrm{kg}^{-1} \mathrm{Zn}\right.$, $100 \mathrm{mg} \mathrm{kg}^{-1} \mathrm{~Pb}$, and $4 \mathrm{mg} \mathrm{kg}^{-1} \mathrm{Cd}$ ) [23].

The overall pollution status of the surface soils by the heavy metals was assessed using the Nemerow pollution index (Pn) [22, 24]:

$$
\mathrm{Pn}=\sqrt{\left(\mathrm{P}_{\mathrm{ave}}{ }^{2}+\mathrm{P}_{\max }{ }^{2}\right) / 2}
$$

... where $\mathrm{P}_{\text {ave }}$ is the average of single pollution index of all metals and $\mathrm{P}_{\max }$ is the maximum value of the single pollution index of all metals. Pollution of the surface soils by the heavy metals was classified into five grades based on the Nemerow pollution index $(\mathrm{Pn}<0.7$ is clean, $\mathrm{Pn}$ $0.7-1.0$ is the warning limit, Pn 1.0-2.0 is slightly polluted, $\mathrm{Pn}$ 2.0-3.0 is moderately polluted, and $\mathrm{Pn}>3.0$ is seriously polluted) [14].

The results are presented as the means of five replicates of each estimation, together with standard deviation $( \pm \mathrm{SD})$ of the means. The data was analyzed by ANOVA and the treatments were treated as independent variables. Significant statistical differences of all variables were established using Tukey tests (ANOVA; Statistica 10 software). We also calculated Pearson`s correlation coefficients. 
Table 1. pH value and organic matter content [\%] in soil of investigated sites (mean values $\pm \mathrm{SE} \mathrm{n}=5$ ). The different letters denote significant differences $(\mathrm{p}<0.05)$.

\begin{tabular}{|c|c|c|}
\hline & $\mathrm{pH}$ & Organic matter \\
\hline M1 & $4.27 \pm 0.26 \mathrm{~b}$ & $6.89 \pm 3.24 \mathrm{a}$ \\
\hline L2 & $4.97 \pm 0.20 \mathrm{c}$ & $15.42 \pm 9.18 \mathrm{a}$ \\
\hline J3 & $4.30 \pm 0.14 \mathrm{~b}$ & $26.48 \pm 8.50 \mathrm{a}$ \\
\hline P4 & $3.67 \pm 0.23 \mathrm{a}$ & $15.75 \pm 1.59 \mathrm{a}$ \\
\hline PB5 & $3.46 \pm 0.03 \mathrm{a}$ & $29.87 \pm 8.49 \mathrm{~b}$ \\
\hline K6 & $3.45 \pm 0.10 \mathrm{a}$ & $22.26 \pm 9.41 \mathrm{a}$ \\
\hline
\end{tabular}

\section{Results}

Analysis of the studied soils' acidity indicated that the $\mathrm{pH}$ was acidic. The lowest soil $\mathrm{pH}$ value was noted at site K6 (3.45), while the highest was observed at site L2 (4.97) (Table 1). In the outer layer of the soil from the analyzed sites, the amount of organic matter ranged from $6.89 \%$ at site M1 to $29.87 \%$ at site PB5 (Table1).

There were significant differences in the content of the metals studied $\left(\mathrm{HNO}_{3}\right.$ extracted and $\mathrm{CaCl}_{2}$ extracted) between the polluted and potentially clean sites. A concentration several times lower was determined in the fraction of soil extracted with $\mathrm{CaCl}_{2}$. The highest levels of $\mathrm{Cd}, \mathrm{Pb}$, and $\mathrm{Zn}$ in both fractions was observed at site $\mathrm{M} 1 \quad\left(\mathrm{HNO}_{3}\right.$, respectively: $25.54 \mathrm{mg} \mathrm{kg} \mathrm{kg}^{-1}$, $1874.99 \mathrm{mg} \mathrm{kg}^{-1}$, and $871.50 \mathrm{mg} \mathrm{kg}^{-1} ; \mathrm{CaCl}_{2}-8.59 \mathrm{mg} \mathrm{kg}^{-1}$, $37.20 \mathrm{mg} \mathrm{kg}^{-1}$, and $\left.477.75 \mathrm{mg} \mathrm{kg}^{-1}\right)$. The highest levels of $\mathrm{Fe}\left(3584.40 \mathrm{mg} \mathrm{kg}^{-1} \mathrm{HNO}_{3}\right.$ and $61.90 \mathrm{mg} \mathrm{kg}^{-1} \mathrm{CaCl}_{2}$ ) were observed at sites J3, PB5, and L2. Detailed results on the levels of the heavy metals (both fractions) are presented in a paper by Kandziora-Ciupa et al. [25]. Nemerow pollution index ranges from 0.97 in $\mathrm{K} 6$ stand to 11.11 in the soil of M1, the most polluted site (Table 2).

Mean activities of the examined enzymes are presented in Figs 1-4. The highest activity of acid phosphatase was observed in the soil collected in May at site L2 (7208.69 $\left.\mu \mathrm{g} \mathrm{pNf} \mathrm{g}{ }^{-1} \mathrm{~d} . \mathrm{m} \mathrm{h}^{-1}\right)$, and the lowest

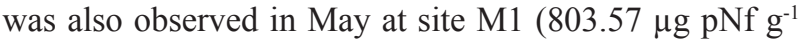

Table 2. Single pollution index (SPI) and Nemerow pollution index (NPI) (for acid extracted elements) in soil of investigated sites.

\begin{tabular}{|c|c|c|c|c|}
\hline & SPI-Cd & SPI-Pb & SPI-Zn & NPI \\
\hline M1 & 4.91 & 14.02 & 2.40 & 11.11 \\
\hline L2 & 1.40 & 2.79 & 1.27 & 2.35 \\
\hline J3 & 1.74 & 4.31 & 1.33 & 3.51 \\
\hline P4 & 0.60 & 2.18 & 0.38 & 1.71 \\
\hline PB5 & 1.08 & 2.55 & 0.35 & 2.03 \\
\hline K6 & 0.16 & 1.27 & 0.12 & 0.97 \\
\hline
\end{tabular}

d.m. $\mathrm{h}^{-1}$; Fig. 1). The highest mean activity of dehydrogenases in soil was observed in the soil at site L2 (17.05 $\mu \mathrm{g}$ TPF $\mathrm{g}^{-1}$ d.m. $\left.16 \mathrm{~h}^{-1}\right)$ in May, and the lowest at site M1 $\left(0.21 \mu \mathrm{g}\right.$ TPF $\mathrm{g}^{-1}$ d.m. $\left.16 \mathrm{~h}^{-1}\right)$ in September (Fig. 2). At all sites the highest dehydrogenase activity was observed at the beginning of the growing season. In September no dehydrogenase activity was observed at site J3. The highest mean activity of $\beta$-glucosidase was observed in September at site J3 (7359.91 $\mu \mathrm{g}$ saligenin $\mathrm{g}^{-1}$ d.m. $3 \mathrm{~h}^{-1}$ ), and the lowest in July at site PB5 (376.78 $\mu$ g saligenin $g^{-1}$ d.m. $3 h^{-1}$; Fig. 3). Similar to the activityofdehydrogenase, thehighestmeanactivityofurease was also observed at the beginning of the growing season (L2: $253.56 \mu \mathrm{g} \mathrm{N} \mathrm{g}^{-1}$ d.m. $3 \mathrm{~h}^{-1}$ ), and the lowest in September (M1: $17.29 \mu \mathrm{g} \mathrm{N} \mathrm{g}^{-1}$ d.m. 3h-1 ; Fig. 4).

\section{Discussion}

Bioavailability is an important factor when evaluating metal toxicity [5]. Total concentration of elements in soil cannot be considered a good indicator of bioavailability [26]. The distribution and abundance of total metal concentrations are useful indicators of the extent of soil contamination [27-29], but risk from metals depends on their bioavailability [29-31].

There was a clear difference between the concentrations of the studied metals in the potentially bioavailable extracted fraction of $\mathrm{CaCl}_{2}$, and $\mathrm{HNO}_{3}$ -

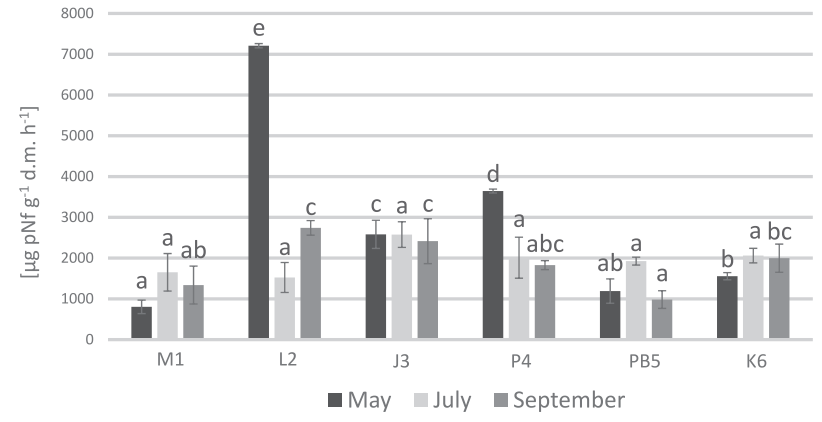

Fig. 1. Acid phosphatase activity in soil of investigated sites (mean values $\pm S E, n=5$ ). The different letters denote significant differences between enzyme activity in the same month $(\mathrm{p}<0.05)$.

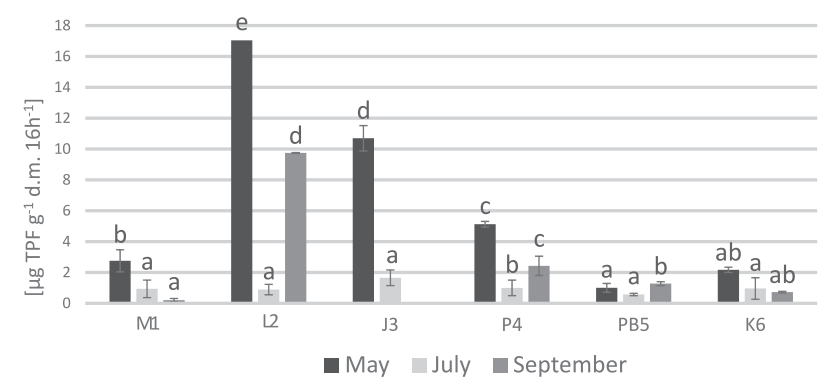

Fig. 2. Dehydrogenase activity in soil of investigated sites (mean values $\pm S E, n=5$ ). The different letters denote significant differences between enzyme activity in the same month $(\mathrm{p}<0.05)$. 


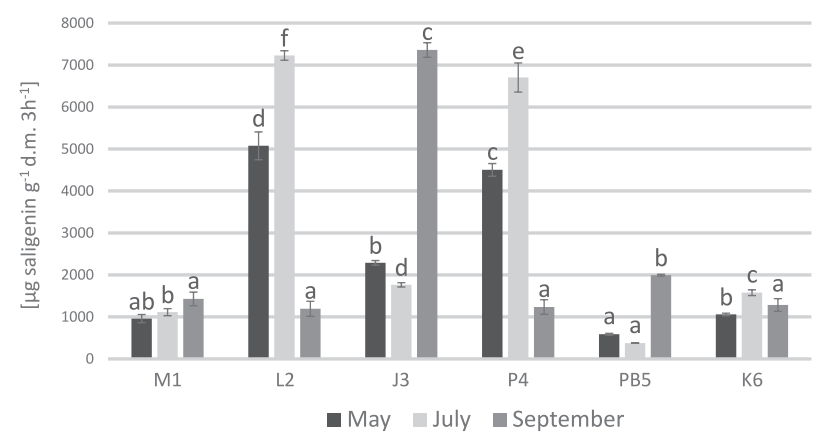

Fig. 3. $\beta$-glucosidase activity in soil of investigated sites (mean values \pm SE, $n=5$ ). The different letters denote significant differences between enzyme activity in the same month $(p<0.05)$.

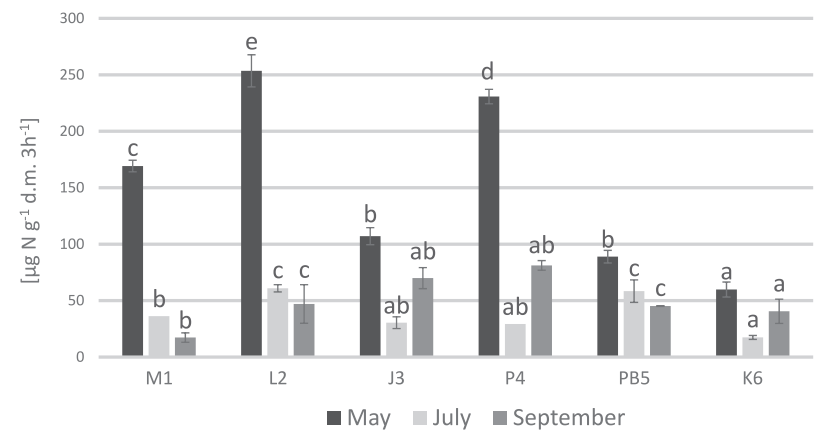

Fig. 4. Urease activity in soil of investigated sites (mean values $\pm \mathrm{SE}, \mathrm{n}=5$ ). The different letters denote significant differences between enzyme activity in the same month $(p<0.05)$.

extracted fractions at all the studied sites [25]. The order of metals in the soil fraction extracted with $\mathrm{HNO}_{3}$ was as follows: $\mathrm{Fe}>\mathrm{Pb}>\mathrm{Zn}>\mathrm{Cd}$ and for the $\mathrm{CaCl}_{2}$ extracts it was $\mathrm{Zn}>\mathrm{Cd}>\mathrm{Pb}>\mathrm{Fe}$. In most cases, soils from polluted sites had a higher concentration (often above the permissible concentrations for soil according to Environmental Regulation 2002 [23]) of heavy metals (both fractions) than in areas potentially free of contaminants. A similar correlation was reported by Kafel et al. [32]. Also, Nemerow pollution indices indicated serious pollution with heavy metals at sites $\mathrm{M} 1$ and $\mathrm{J} 3$, moderate pollution at L2 and PB5, slight pollution at P4, and the warning limit at $\mathrm{K} 6$.

Changes in physico-chemical properties of forest soils under the influence of industrial pollution are not adequate indicators of soil degradation. A more sensitive indicator is change in soil enzyme activity that catalyzes biochemical processes crucial for the forest soil fertility and productivity in the forest ecosystem [33]. Phosphatases in soil ecosystems are believed to play critical roles in $\mathrm{P}$ cycles through the stimulation of conversions of organic phosphor compounds into inorganic phosphates, directly available to plants and soil organisms [34-36]. In this paper the lowest activity of acid phosphatase was observed at sites M1 and PB5. There was a negative correlation between the activity of the acid phosphatase and the level of bioavailable forms of $\mathrm{Cd}, \mathrm{Fe}$, and $\mathrm{Zn}$
Table 3. The correlation coefficients between heavy metal content $\left(\mathrm{CaCl}_{2}\right.$ fraction $)$ and $\mathrm{pH}$ value in studied soil samples and enzyme activity $(\mathrm{p}<0.05)$; NS: not significant.

\begin{tabular}{|c|c|c|c|c|c|}
\hline & $\mathrm{Cd}$ & $\mathrm{Fe}$ & $\mathrm{Pb}$ & $\mathrm{Zn}$ & $\mathrm{pH}$ \\
\hline acid phosphatase & -0.32 & -0.29 & $\mathrm{NS}$ & -0.28 & 0.33 \\
\hline dehydrogenases & $\mathrm{NS}$ & -0.34 & $\mathrm{NS}$ & $\mathrm{NS}$ & $\mathrm{NS}$ \\
\hline$\beta$-glucosidase & -0.28 & -0.42 & $\mathrm{NS}$ & $\mathrm{NS}$ & 0.39 \\
\hline urease & $\mathrm{NS}$ & $\mathrm{NS}$ & $\mathrm{NS}$ & $\mathrm{NS}$ & $\mathrm{NS}$ \\
\hline
\end{tabular}

(Table 3). In a study on soil enzymatic activity in forests in areas affected by nitrogen production plants, Bielińska and Domżał [37] also showed an adverse effect of $\mathrm{Cd}$ and $\mathrm{Zn}$ on the activity of phosphatases. Balyaeva et al. [38], Nadgórska-Socha et al. [39], and Effron et al. [40] also observed a decrease in the activity of acid phosphatase under the influence of heavy metals. Dehydrogenases are intracellular enzymes involved in the microbial metabolism of oxygen [15]. In this paper we found no decrease in the activity of dehydrogenase at sites more burdened by trace elements despite many authors [e.g., 4143] showing the highly inhibitory effect of heavy metals on the activity of dehydrogenases. We only observed the negative correlation between the activity of these enzymes and the level of available fractions of Fe (Table 3 ) at site PB5, where the level was the highest.

$\beta$-glucosidase (cellobiase) is a common - and the most important - soil enzyme [37]. It takes part in the mineralization of cellulose, catalyzes the reactions of cellobiose degradation into two glucose molecules, and cleaves glucose molecules from the non-reducing ends of cello-oligosaccharides [44]. $\beta$-glucosidase is a useful indicator of soil quality and its activity may indicate changes in the level of organic carbon long before measurements by other methods [36]. Obtained results show a negative correlation between the concentration of bioavailable forms of $\mathrm{Cd}$ and $\mathrm{Fe}$ and the activity of $\beta$-glucosidase (Table 3 ). The mean activity of $\beta$-glucosidase in soils at the examined sites was significantly less at sites M1 (with the highest level of bioavailable fractions of cadmium), and PB5 and K6 (the highest levels of bioavailable fractions of $\mathrm{Fe}$ ).

Many authors $[45,46]$ confirm the negative effects of trace metals on the activity of $\beta$-glucosidase. Jiang et al. [47] also confirm a decrease in the activity of $\beta$-glucosidase induced by an increase in the level of cadmium in soil near a copper mill. The decrease in the activity of urease (an extracellular enzyme hydrolyzing C-N bonds in some amids and urea) seen in this study is not entirely tantamount to increased soil pollution. The lowest mean activities of this enzyme were observed at site M1 (the highest levels of trace metals in the soil) while low activities were observed at less polluted sites (e.g., K6 - the lowest soil pH). Also, Madejón et al. [48], Castaldi et al. [49], and Friedlová [15] found no correlation between the increased concentrations of trace metals and urease activity. Some studies demonstrated significant relationships between 
soil enzymes and other soil characteristics, but those relationships largely depended on the species of enzyme and the environmental variable [50, 43]. A factor that may largely determine soil enzyme activity is its organic matter. In the present study, we found no statistically significant correlation between the activity of the enzymes and organic matter content in the soil. This could be related to the low level of humic substances in the total organic matter, and consequently limited availability of easily assimilable carbon, which determines the development of soil bacteria that produce enzymes [51]. Effron et al. [40] reported that enzyme activity was sensitive to changes in $\mathrm{pH}$. We found a positive correlation between the activity of acid phosphatase and soil $\mathrm{pH}$, and the same for $\beta$-glucosidase.

According to Acosta-Martinez and Tabatabai [52], Madejón et al. [48], and Makoi and Ndakidemi [35], $\beta$-glucosidase is also very sensitive to changes in $\mathrm{pH}$ (optimum pH range is 6.2-7.8), which is confirmed in this study by an increase in the activity of this enzyme at sites with the highest soil $\mathrm{pH}$ (L2 and J3) and decrease $\beta$-glucosidase activity at sites with the lowest $\mathrm{pH}$ (PB5 and K6) (Table 3, Fig. 3).

Despite the fact that a relationship between urease activity and $\mathrm{pH}$ levels was not significant, we observed that activity of this enzyme was lowest at sites with the lowest soil pH (below 3.5, as for PB5 and K6 - Table 1 and Fig. 4) while optimum $\mathrm{pH}$ for urease amounts to 6-7 [53]. Weakening of enzymatic activity in soil with the increase of soil acidity is the effect of destroying ion and hydrogen bonds in the enzyme's active center [54, 53].

Because they derive from living organisms, soil enzymes are season-dependent macromolecules [5]. In this work, in most cases the higher activity of the enzymes was noticed in the spring and summer. Also, Zhang et al. [55] found that there were seasonal differences in the effect of heavy metals on soil enzymes, with the effect of the heavy metals more obvious in spring and summer than in autumn [5].

\section{Conclusions}

The examined sites are characterized by diverse levels of soil pollution. Single pollution and Nemerow indexes indicated that two sites (M1 and J3) were severely contaminated with heavy metals. None of the examined sites can be classified as clean. Soil $\mathrm{pH}$ had the highest influence on enzyme activity; low soil $\mathrm{pH}$ could be one reason for low urease and $\beta$-glucosidase activities at lesspolluted sites. Less activity of urease and $\beta$-glucosidase in low $\mathrm{pH}$ soil could mean decreasing their effectiveness on chemical reactions. The effects of heavy metals on enzyme activity varied considerably among the elements and enzymes. Soil enzymatic activity decreased significantly with increasing contamination by heavy metals especially acid phosphatase and $\beta$-glucosidase. Therefore, enzyme activity analysis and factors influencing them seem to be a useful tool for monitoring forest soil quality under heavy metal pollution.

\section{Acknowledgements}

This work was supported by the Polish State Committee for Scientific Research as project No. N N304 378938.

\section{References}

1. PRESCOT L.M., KLEIN D.A., HARLEY J.P. Microbiology. $5^{\text {th }}$ e. USA: McGraw Hill, 32, 2001.

2. FREDERIC O.O., IROHA A.E., OSWALD E.C., Evaluation of the Concentration of selected heavy metals and the effects on soil enzymatic activities in an Abandoned Cement Factory Nigercem Nkalagu and its environs. International Journal of Biochemistry Research \& Review. 4 (1), 16, 2014.

3. TRASAR-CEPEDA C., LEIRÓS M.C., GIL-SOTRES F. Hydrolytic enzyme activities in agricultural and forest soils. Some implications for their use as indicators of soil quality. Soil Biol. Biochem., 40, 2146, 2008.

4. BIERZA W., NADGÓRSKA-SOCHA A., MAŁKOWSKA E., CIEPAE R. Evaluation of the soil enzymes activity as an indicator of the impact of anthropogenic pollution on the Norway spruce ecosystems in the Silesian Beskid. Ecol. Chem. Eng. A. 19 (7), 707, 2012.

5. KARACA A., CETIN S.C., TURGAY O.C., KIZILKAYA R. Effects of heavy metals on soil enzyme activities. In: Sherameti I, Varma A, editors. Soil heavy metals. Soil Biology 19. Springer-Verlag, Berlin Heidelberg, 237, 2010.

6. HASSAN W., AKMAL M., MUHAMMAD I., YOUNAS M., ZAHID K.R., ALI F. Response of soil microbial biomass and enzymes activity to cadmium (Cd) toxicity under different soil textures and incubation times. AJCS, 7 (5), 674, 2013.

7. MEGHARAJ K.V.M., SETHUNATHAN N., NAIDU R. Bioavailability and toxicity of cadmium to microorganisms and their activities in soil: a review. Adv Environ Res. 8, 121, 2003.

8. SHEN G., LU Y., ZHOU Q., HANG J. Interaction of polycyclic aromatic hydrocarbons and heavy metals on soil enzyme. Chemosphere. 61, 1175, 2005.

9. SARDAR K., QING C., EL-LATIF H.A., YUE X., JIZHENG H. Soil enzymatic activities and microbial community structure with different application rates of $\mathrm{Cd}$ and $\mathrm{Pb}$. J Environ Sci. 19, 834, 2007.

10. ROSSEL D., TARRADELLAS J., BITTON G., MOREL J. Use of enzymes in soil ecotoxicology: a case of dehydrogenase and hydrolytic enzymes. In: Tarradellas J, Bitton G, Rossel D, editors. Soil ecotoxicology. Lewis Publishers, 179, 1997.

11. KIELISZEWSKA-ROKICKA B. In: Dahm H., Pokojska-Burdziej A., ed. Microorganisms of the soil environment-physiological, biochemical, genetic aspects. Adam Marszałek Publisher, 37, 2001.

12. ŚLIWIŃSKA-WYRZYCHOWSKA A., NADGÓRSKASOCHA A. The effect of heavy metal pollution and prescence of Lycopodium annotinum on soil enzyme activity. Chem. Met. Alloys 4, 38, 2011.

13. KHAN S., CAO Q., HESHAM A.E.L., XIA Y., HE J.Z. Soil enzymatic activities and microbial community structure with different application rates of $\mathrm{Cd}$ and $\mathrm{Pb}$. J Environ Sci. 19, 834, 2007.

14. HINOJOSA M.B., CARREIRA J.A., GARCIA-RUIZ R. Microbiological rates and enzyme activities as indicators of functionality in soils affected by the Aznalcóllar toxic spill. Soil Biol Biochem. 36, 1637, 2004.

15. FRIEDLOVÁ M. The Influence of Heavy Metals on Soil 
Biological and Chemical Properties. Soil Water Res. 5 (1), 21, 2010.

16. SCHINNER F., ORHLINGER R., KANDELER E., MARGENSIN R. Methods in biology. Springer Verlag. Berlin Heidelberg, 171, 213, 241, 1995.

17. HOFFMANN G., DEDEKEN M. Eine methode zur kolorimetrischen bestimmung der $\beta$-glucosidase-aktivität im Boden. [A method for the colorimetric determination of the $\beta$-glucosidase activity in the soil] Plant Nut Soil. 100, 195, 1965.

18. STROBL W., TRAUNMÜLLER M. $\beta$-glukosidase Activity. In: Springer Labor Method in Soil Biology. Germany, 198, 1996.

19. BOUWMAN L., BLOEM J., RÖMKENS P., BOON G., VANGRONSVELD J. Beneficial effects of the growth of metal tolerant Grass on biological and chemical parameters in cooper and zinc contaminated sandy soils. Minerva Biotec. 13, 19, 2001

20. OSTROWSKA A., GAWLIŃSKI S., SZCZUBIAŁKA Z. Methods of analysis and evaluation of soil and plant properties. Catalog. Institute of Environ Protect, Warsaw 1991 [in Polish].

21. LEI M., ZHANG Y., KHAN S., QIN P., LIAO B. Pollution, fractionation and mobility of $\mathrm{Pb}, \mathrm{Cd}, \mathrm{Cu}$ and $\mathrm{zn}$ in garden and paddy soils from $\mathrm{Pb} / \mathrm{Zn}$ mining area. Environ Monit Assess 168, 215, 2010.

22. HU Y., LIU X., BAI J., SHIH K., ZENG E., CHENG H. Assessing heavy metal pollution in the surface soils of a region that had undergone three decades of intense industrialization and urbanization. Environ Sci Pollut Res. 20, 6150, 2013.

23. The regulation of Environment Minister about standards of soil and ground quality, The Act Gazette of Poland nr 165 pos. 1358 and 1359 from 09.09 .2002 .

24. CHENG J., SHI Z., ZHU Y. Assessment and maping of environmental quality in agricultural soils of Zhejiang Province, China. Huangjin Kexue 19 (1), 50, 2007.

25. KANDZIORA-CIUPA M., CIEPAŁ R., NADGÓRKSASOCHA A., BARCZYK G. A comparative study of heavy metal accumulation and antioxidant responses in Vaccinium myrtillus L. leaves in polluted and non-polluted areas. Environ Sci Pollut Res. 20 (7), 4920, 2013.

26. NANDGÓRSKA-SOCHA A., PTASIŃSKI B., KITA A. Heavy metal bioaccumulation and antioxidative responses in Cardaminopsis arenosa and Plantago lanceolata leaves from metalliferous and non-metalliferous sites: a field study. Ecotoxicology. 22, 1422, 2013.

27. TOKALIOGLU S., KARTAL S., ELC L. Determination of heavy metals and their speciation in lake sediments by flame atomic absorption spectrometry after a four-stage sequential extraction procedure. Anal. Chim. Acta, 413 (1-2), 33, 2000.

28. XIAO R., BAI J.H., WANG Q.G., GAO H.F., HUANG L.B., LIU X.H. Assessment of heavy metal contamination of wetland soils from a typical aquatic-terrestrial ecotone in Haihe River Basin, North China. CLEAN-Soil, Air and Water 39 (7), 612, 2011.

29. DAO L., MORRISON L., KIELY G., ZHANG C.H. Spatial distribution of potentially bioavailable metals in surface soils of a contaminated sports ground in Galway, Ireland. Environ. Geochem. Health, Online ISSN: 1573, 2012.

30. PROKOP Z., CUPR P., ZLEVOROVA-ZLAMALIKOVA V., KOMAREK J., DUSEK L., HOLOUBEK I. Mobility, bioavailability, and toxic effects of cadmium in soil samples. Environ. Res. 91 (2), 119, 2003.

31. VAN GESTEL C.A.M. Physico-chemical and biological parameters determine metal bioavailability in soils. Sci. Total Environ. 406 (3), 385, 2008.
32. KAFEL A., NADGÓRSKA-SOCHA A., GOSPODAREK J., BABCZYŃSKA A., SKOWRONEK M., KANDZIORA M., ROZPENDEK K. The effects of Aphis fabae infestation on the antioxidant response and heavy metal content in field grown Philadelphus coronarius plants. Sci Total Environ 408 (5), 1111, 2010

33. KOPER J., PIOTROWSKA A., SIWIK-ZIOMEK A. Activity of dehydrogenases, invertase and rhodanase in forest rusty soil in the vicinity of 'Anwil' nitrogen plant in Włocławek. Ecol Chem Eng A. 15 (3), 237, 2008.

34. MATINIZADEH M., KORORI S.A.A., TEIMOURI M., PRAZNIK W. Enzyme activities in undisturbed and disturbed forest soils under oak (Quercus brantii var. persica) as affected by soil depth and seasonal variation. Asian J Plant Sci. 7, 368, 2008

35. MAKOI J.H.J.R., NDAKIDEMI P.A. Selected soil enzymes: Example of their potential roles in the ecosystem. Afr J Biotechnol. 7 (3), 181, 2008.

36. DAS S.K, VARMA A. Role of enzymes in Maintaining Soil Health. In: Shukula G, Varma A, editors. Soil Enzymology. Springer-Verlag Berlin Heidelberg, 25, 2011.

37. BIELIŃSKA E.J., DOMŻAŁ H. Soil enzymatic activity in deteriorated forest ecosystems in the operation area of the Puławy S.A. Nitrogen Factory. Acta Agrophysica. 51, 7, 2001.

38. BALYAEVA O.N., HAYNES R.J., BIRUKOVA O.A. Barley yield and soil microbial and enzyme activities as effected by contamination of two soils with lead, zinc or copper. Biol Fertil Soils. 41, 85, 2005.

39. NADGÓRSKA-SOCHA A., ŁUKASIK I., CIEPAŁ R., POMIERNY S. Activity of selected enzymes in soil loaded with varied levels of heavy metals. Acta Agrophysica. 8 (3), 713, 2006

40. EFFRON D., DE LA HORRA, DEFRIERI A.M., FONTANIVE R., PALMA P.M. Effect of cadmium, copper, and lead on different enzyme activities in a native forest soil. Comm Soil Sci Plant Anal. 35, 1309, 2004.

41. WYSZKOWSKA J., KUCHARSKI J., KUCHARSKI M. Interaction of cadmium with other heavy metals and its influence on the soil biochemical properties. Pol J Environ Stud. 15 (2a), 559, 2006.

42. MIKANOVA O. Effects of heavy metals on some biological parameters. J Geochem Explor. 88, 220, 2006.

43. NADGÓRSKA-SOCHA A., KANDZIORA-CIUPA M., CIEPAE R., MUSIALIK D., BARCZYK G. The Activity of Selected Soil Enzymes, and Soil Contamination with Zinc, Cadmium and Lead in the Vicinity of the Zinc Smelter "Miasteczko Śląskie". Ecol. Chem. Eng. A. 20 (1), 123, 2013.

44. RUSSEL S., GÓRSKA E.B., WYCZÓŁKOWSKI A.I. Enzymes taking part in hydrolysis of cellulose Acta Agrophysica. 3, 27, 2005 [In Polish].

45. DENG S.P., TABATABAI M.A. Cellulase activity of soils: effect of trace elements. Soil Biol Biochem. 27, 977, 1995.

46. GEIGER G., BRANDI H., FURNER G., SCHULIN R. The effect of copper on the activity of cellulase and B-glucosidase in the prsecence of montmorillonite or Al- montmorillonite. Soil Biol Biochem. 30, 1537, 1998.

47. JIANG J., WU L., LIN., LUOY., LIU L., ZHAOQ., ZHANG L., CHRISTIE P. Effects of multiple heavy metal contamination and repeated phytoextraction by Sedum plumbizincicola on soil microbial properties. Eur J Soil Biol. 46 (1), 18, 2010.

48. MADEJÓN E., BURGOS P., LÓPEZ R., CABRERA F. Soil enzymatic response to addition of heavy metals with organic residues. Biol Fert Soils. 34, 144, 2001.

49. CASTALDI S., RUTIGLIANO F.A., VIRZO DE SANTO 
A. Suitability of soil microbial factors as indicators of heavy metal pollution. Water Air Soil Poll. 158, 21, 2004.

50. SHI Z.J., LU Y., XU Z.G., FU S.L. Enzyme activity of urban soils under different land use in the Shenzen city, China. Plant Soil Environ. 54 (8), 341, 2008.

51. BIELIŃSKA E.J. Ecological characteristics of soils in urban allotments. Journal of Res and Applic in Agri Eng. 51 (2), 13, 2006.

52. ACOSTA-MARTINEZ V., TABATABAI M.A. Enzyme activities in a limed agricultural soil. Biol Fertil Soils. 31, 85, 2000.
53. BŁOŃSKA E. Enzyme activity in forest peat soils. Folia For Pol Ser A. 52 (1), 20, 2010.

54. FRANKENBERGER W.T.J., JOHANSON J.B. Effect of $\mathrm{pH}$ on enzyme stability in soils. Soil Biol. Biochem. 14, 433, 1982.

55. ZHANG Y., ZHANG H., SU Z., ZHANG C. Soil microbial characteristics under long-term heavy metal stress: a case study in Zhangshi wastewater irrigation area, Shengyang. Pedosphere. 18, 1, 2008. 